Journal of Social Sciences (COES\&RJ-JSS)

ISSN (E): 2305-9249 ISSN (P): 2305-9494

Publisher: Centre of Excellence for Scientific \& Research Journalism, COES\&RJ LLC

Online Publication Date: $1^{\text {st }}$ April 2018

Online Issue: Volume 7, Number 2, April 2018

https://doi.org/10.25255/jss.2018.7.2.86.102

\title{
Exploring Relationships between Education Level and Unemployment Grabe Mpendulo
}

Department of Economic and Business Sciences, Walter Sisulu University mpendulograbe@gmail.com https://orcid.org/0000-0001-5905-3252

Eric E. Mang'unyi

School of Business, The Catholic University of Eastern Africa

*mangunyie@gmail.com https://orcid.org/0000-0002-5035-104X

\author{
Abstract
}

Purpose: Unemployment has been a subject for numerous studies and recent debates in South Africa and beyond. This paper explores the relationship between education level and unemployment among the youth in four municipalities in O.R Tambo District (ORTDM), Eastern Cape, South Africa. The theory of human capital provided the theoretical underpinning of the connection between education level and unemployment, and also the theory was used to interpret the findings. It is assumed that by conducting this investigation, an important contribution is made to theoretical developments in the education and jobs sectors literature and policy in South Africa. Research methods: The study participants were selected using the systematic random sampling since the study employed a quantitative research paradigm. The cross-sectional survey design was implemented. The data consisted of 120 self-completed survey questionnaires from the studied employable young people. The crosstabulation, correlation, chi-suqare data analyses methods were used while the multiple regression model developed was used to test the relationships. Findings: From the analyses, relationships were established such that educational level was found to positively relate to unemployment and was also found to have the highest effect on unemployment. Furthermore, result show negative correlation between economic status and education qualification, while it was positively correlated to unemployment. Lastly, a weak linear relationship exists between level of education and economic status. Implications for research and practice: The findings provide an opportunity for education policy makers to collaborate with the government(s) to develop strategies that favour employment. The results mean that a recurring production of education and training into the labour market is not accompanied by a reduction in unemployment. Future studies may investigate other issues responsible for increasing unemployment in the country despite economic improvement as well as the moderating role of race.

Key words:

Training, skills, skill attainment, youth, joblessness, South Africa

\section{Citation:}

Mpendulo, Grabe; Mang'unyi, Eric E.; (2018). Exploring Relationships between Education Level and Unemployment; Journal of Social Sciences (COES\&RJ-JSS), Vol.7, No.2, pp:86102; https://doi.org/10.25255/jss.2018.7.2.86.102. 


\section{INTRODUCTION}

Education and skill level development correlates positively with a country's economic output. Despite this fact, South Africa's workers' skill level has increased insignificantly since independence, a 3.3\% economic growth notwithstanding (Industrial Development Corporation [IDC] 2013, p. 1). The importance of schools and universities in preparing citizens for life through development of skills is acknowledged. This development through provision of literacy and numeracy skills help to open job opportunities (Cazes \& Verick, 2013). Human capital paradigm assumes that ceteris paribus, the number of years spent in schooling system increases one's ability to get a job (Cazes \& Verik, 2013, p. 10). ${ }^{1}$ However, it is argued that the nature of unemployment of skilled workers is a complex one, since it relates to many factors such as the quality of education, lack of experience, discrimination and labour market inflexibility, labour legislation as well as other structural elements factors (van de Rheede, 2012, p. 1). Oluwajodu (2013, p. 1) supports this view and asserts that unemployment is a socio-economic challenge that reduces economic welfare and output and erodes human capital.

South Africa is predominantly a host to four races namely Blacks, Coloured, Whites and Indians/Asians, which suffer unemployment and skill disparity. Notably, education level among black youth has developed dismally over the years than was expected (Statistics South Africa [Stats SA], 2015). Recent research (Cedefop, 2015, p. 20) attests to this fact by postulating that unemployment and education mismatch have a positive relation.

Like any other developing economy, South Africa has individuals who are un-skilled, semi-skilled and skilled. According to Construction Industry Development Board (2015, p. 6), $46 \%$ of South African's labour force are semi-skilled, $29 \%$ unskilled while only $25 \%$ skilled. This implies that a high number of the labour force is either semi-skilled or unskilled, a situation not so different to other developing economies like Ghana (BaahBoateng, 2015). A study by Stats SA (2014) on the relationship between employment, unemployment and economic growth found $13.7 \%, 36.1 \%$ and $15.1 \%$ unemployment rates for 2008, 2011 and 2013 respectively among youth, which were higher compared to that of adults. In addition, whereas Indians/Asians rate dropped and those for white being relatively lower, unemployment rate among black youth increased in the same periods (Stats SA, 2014). Unemployment and education levels particularly among black young people who stand at 70\% in the Eastern Cape Province (Rogan \& Reynolds, 2014, p. 2) compared to other races is worrying, therefore, (Stats SA, 2015). Oluwajodu et al. (2015) holds that the young South Africans number is ever increasing hence a contributing factor.

Jacob (2014) asserts that a number of measures exist to help curb the growing unemployment. South Africa has programmes to combat unemployment such as employment subsidy, which is used to minimise hiring costs while emboldens trained young people in their quest to find work (National Treasury, 2011, P. 7). Nonetheless, this seems not to be working (IDC, 2013, p. 21). There was an increase in the rate of

\footnotetext{
${ }^{1}$ Further discussion on human capital theory is dealt at length later in this paper.
} 
unemployment among youth in six provinces, excluding Western Cape, Gauteng and KwaZulu-Natal (Stats SA, 2015).

Recent studies point to lack of symmetry between education, government and training institutions (Jacob, 2014; Simiyu and Sambu, 2012; Udinn and Uddin, 2013). Festus, Kasango, Moses and Yu (2015, p. 3) posit a positive relationship between unemployment and wage inflexibility within a labour market. Stats SA (2015) a negative relationship between education level and unemployment. Baah-Boateng (2015) study postulates that unemployment increases with education while Gaspar (2009) found education and region to be the main determinants of the probability of becoming unemployed.

Studies carried out have justified the link between unemployment, education and other factors (Baa-Boateng, 2015; Gaspar, 2009; Oreopoulos, von Wachter, \& Heisz, 2012) with a small number of them focusing on the South African context (Festus et al., 2015; Oluwajodu et al., 2015; Stats SA, 2013, 2015). This study is different as it focuses on educated/trained young people who are unemployed. Some researches have reported that unemployment impacts greatly particularly on young people in South Africa (Stats SA, 2015) while others have insisted that results are still mixed (Riddell \& Song, 2011), thus continue to explore (Oluwajodu et al., 2015). This investigation is, thus, an important contribution to theoretical developments in the education and jobs sectors in South Africa. Noting the deficiency of context specific research the current study attempted to fill a gap in the knowledge base by investigating the relationship between education level and unemployment.

Unemployment is a phenomenon that occurs when a person who is actively searching for employment is unable to find work. Griffiths and Rotheim (2007) state that unemployment is a key determining factor of the strength of an economy. Internationally, unemployment is defined as all persons without work, who are currently available for work or those seeking work (Griffiths and Rotheim, 2007; Weir-Smith, 2014). Some researchers define unemployment by the ratio of the number of people who are unemployed to the number of people in the labour force (Blanchard and Johnson, 2013). However, the business cycle determines on whether the unemployment rate is high or low (Blanchard and Johnson, 2013).

\section{Reasons for unemployment}

Unemployment among youth ${ }^{2}$ is caused by numerous reasons. During economic downtown, the youth are more vulnerable as opposed to their older colleagues (Oluwajodu et al. 2015 , p. 1) because their population is increasing rapidly, lack job experience and have lower level of education (Baah-Boateng 2015, p.404; Cloete 2015, pp. 513-514). In addition, they have inadequate job-hunting experience and labour market information. Another factor is the negative attitude they exhibit towards work (Sha, 2006). In recession times, they are likely relative to the old lose their jobs because

\footnotetext{
${ }^{2}$ This study uses the terms youth and young people to refer to the same thing therefore, conceptualises young people in reference to the Department of Basic Education (2011) definition as those within the age bracket of $15-34$ years.
} 
of organisational rationalisation policies such as Last-In-First-Out (Baah-Boateng 2015). Therefore, it is difficult to separate growing unemployment and macro and micro economic picture of South Africa (Oluwajodu et al., 2015).

\section{Making the Link between Education Level and Unemployment}

A number of sources inter alia literature, research studies and surveys indicate that globally, although some studies have postulated a unidirectional causality, the link between education level and unemployment remains elusive, since different researchers used different approaches in its exploration. Whereas skills and education level constitutes a key ingredient to filling the job openings and success in career (Archer and Chetty, 2013), lack of necessary productive capability of the labour force determined by education level to meet the requirement of job openings creates unemployment problem (Baah-Boateng, 2015). Oluwajodu et al. (2015) study among unemployed graduates, recently employed and managers in the banking sector on issues perceived to be the causes of graduate unemployment in South Africa revealed skill mismatch, institution attended and varying employer expectations as key impediments. The authors further stated that graduate employment remains problematic because it wastes scarce human capital, which is pegged on the economy in the long run (Oluwajodu et al., 2015). Goldin (2014) found a strong correlation between education level and economic growth.

Oreopoulos et al. (2012) posits a small effect of unemployment on number of years of schooling. This is reinforced by Cutler et al. (2015) study which found statistically significant relationship between years of schooling and unemployment. Riddell and Song (2011) studied the causal relation between unemployment, education and reemployment of unemployed workers by looking at years of schooling, state of residence, age, gender, race, marital status and metropolitan status. By regressing the aforementioned variables, results couldn't ascertain on whether/or not there is positive relationship between the said variables. However, their research found a positive relationship between education level and employment (Riddell and Song, 2011). Hence, is an increase in education level decreases unemployment? Cutler et al. (2015) asserts that higher unemployment rate is associated with lower income, lower life satisfaction, greater obesity, more smoking and drinking later in life. The authors' further state that with high unemployment rate caused by the aforementioned outcomes, education level plays a proactive role in reducing high percentage of unemployment.

Applegate, Chiem and Sanders (2014) study in different US states revealed a significant negative correlation between adults' education levels and unemployment. In addition, there was no significance between university degree holders or higher and unemployment rate. The study concluded that having at least a high school diploma significantly decreases unemployment rate (Applegate et al., 2014). According to (Nel and Neale-Shutte, 2013) employable graduates need exposure to work-integrated or experiential learning and improve relations between university academics and employers. A comparative study between long-term and short-term unemployment relative to education found that academic degree is more effective on reducing the likelihood of short-term than long-term unemployment (Núñez and Livanos, 2010). Dimian (2015) study on unemployment in relation to labour market mismatches at 
sectorial, occupational and educational level found that unemployment rate in countries depends on the economic cycle and that youth were mostly affected. The study recommended that developing countries labour market need educated people.

This study reviewed contributions by gurus in the field such as (Cazes and Verik, 2013; Cedefop, 2015 and Cutler et al., 2015) in addition to the work of (for example Dimian, 2015; Goldin, 2014; Riddell and Song, 2011). Specific related frameworks reviewed included the human capital framework, labour market rigidity and job search model. Given the limited dominance of studies on the connection between education level and unemployment, this study attempts to fill that gap while also trying to establish differences in the level of education among races in relation to unemployment. The study offers potential to rethink existing education and training systems towards facilitating programmes that would meet job market demands in line with national development plans to reduce insistent unemployment in South Africa.

\section{Theoretical framework - Human capital theory}

The term human capital in economic sense derived from a need to understand social and economic behaviour (Goldin, 2014). This theory assumes that while the stock of knowledge increases, the original (cognitive) knowledge can be continuously elaborated and developed through the relationship between external (un-cognitive) knowledge, information, skills, and experiences (Dae-Bong, 2009, p. 4). Investment in human capital relates to the stock of knowledge and skills possessed by the worker which contributes to a worker's production capacity (Teixeira, 2014). The ability of nations to foster human capital accumulation relies on the capability and enablement of existing institutions for legal and "extra-legal" rules that define property rights in man (Goldin, 2014, p. 5). However, the aforementioned author cautions that the accumulation of human capital is likely to be suboptimal where people cannot make credible, long term decisions on investment. Schools and training institutions play a significant role in determination of skills and knowledge transfer (Dae-Bong, 2009, p. 5; Laureys, 2015). Continuous education creates human capital hence an increase in the aggregate productivity level of the economy (Micer, 1991). However, an individual invests in education if the discounted returns exceed the costs of investment (Goldin 2014, p. 10). Positive effects of education on economic growth lead a country to invest in human capital i.e. HE (Erdem and Tugcu, 2012). That said, it is apparent that continuous investment in human capital lead to increase in income in turn, boosting an individual's self-esteem.

Furthermore, the theory's two-period model expressed in equation form as $\left[\left(E_{2} / w_{2}\right)-\right.$ $\left.1] / 1+r>\left(C+w_{1}\right) / w_{2}\right]$ posits that investment in human capital occurs in the first period if work is chosen, while $W_{2}$ is the second period non-investment wage if investment is chosen where cost is $C$. $E_{2}$ is the second period investment wage $\left(>w_{2}\right)$ and the individual can borrow at r. Goldin (2014, p. 10) also states that an individual is free to invest only if the relationship between discounted returns, expressed as a fraction of the second noninvestment wage, exceed the cost (direct costs of c plus the opportunity cost of the first period non-investment wage, $w_{1}$ ). 
On the other hand, some authors (Van der Merwe, 2009) look at HCT in relation to rate of return with investment in education. The aforementioned authors observe HCT in terms of demand for HE programmes and individuals' labour market expectations and experiences. A study by (Van der Merwe, 2009) found that graduates labour market expectations and experiences are less than well matched implying that demand for university programmes may be misinformed, further casting doubt on human capital theory credibility to explain the demand for university programmes. Despite the setbacks that may be associated with the theory, this study was anchored on HCT because it relates education level and labour market productivity which is advantageous to the economy.

\section{Research objectives}

1. To determine youth's perception of their level of education/skills training in relation to unemployment.

2. To ascertain the association between education level of youth and unemployment.

3. To analyse results of an empirical survey undertaken amongst youth at ORTDM and to report thereon.

\section{METHOD}

\section{Research Design}

This study used a quantitative approach to collect data. In particular, cross-sectional survey design was used since a large size of the population was involved. Responses from skilled youth were sought which enabled to ascertain the nexus between education level and unemployment. Through cross-sectional survey design, we employed a survey questionnaire which enabled collection of structured data that provided the fundamental connection between empirical observation and the mathematical expression of existing quantitative causal relationships when analysed (Creswell, 2015).

\section{Research Sample}

The target population for this study was all youth in the 4 local municipalities (King Sabata Dalidyebo, Mhlontlo, Port St. Johns, and Ingquza Hill) in ORTDM eligible to work and was randomly selected. These units were thought to be the most common in the population under investigation (Bless, Higson-Smith \& Sithole 2013, p. 172). Using the pre-defined sample size calculator proposed by (Gujarati, Porter \& Gunasekar, 2013) for use in surveys the sample comprised 120 youths selected using stratified purposeful random sampling that participated in this study. Thereafter, within each stratum (municipality), systematic simple random sampling was implemented to elect participants in the survey.

\section{Research Instruments and Procedures}

The collection of data was through personally administered and adapted closed-ended questionnaire (Eiselen, Uys \& Potgieter 2005). Statistical documents and journals were also consulted. Since the primary objective of the research was to investigate the connection between education level and unemployment, the questionnaire was designed with the aim of informing the following research questions: (1) what is the 
association between level of education and unemployment? (2) Is there a difference in the education levels among youth of different races? Questionnaires were used because they are easily administered to a large population at a low cost, are unequivocal and that they are easily analysed scientifically. Before adapting the questionnaire, it was sent to experts in the business field with relevant experience for their subjective comments. The questionnaire was divided into sections measuring youth skills where wording for some items was modified slightly according to reviewer comments. For example, skilled youth were asked to rank in order of importance each of the reasons for not getting employed. As well, they were asked for their perception about skills acquisition. Participant profile of interest such as age, gender, race, education level was also gathered. Before actual data collection, the instrument was pilot-tested among youth in Mthatha town. Dubious questions were taken out and some were corrected in a manner in which they became unequivocal.

\section{Data Analysis}

The study adopted different approaches as proposed by Creswell (2014) in data analysis. The data were screened and edited to detect errors and omissions. Then it was serialised in readiness for coding, entry and analysis (Cooper \& Schindler, 2008; Sekaran 2016 p. 273). Thereafter, data were captured into the computer for easier handling and conversion to information that was needed. Using SPSS version 23, descriptive statistics namely frequencies, percentages and crosstabulation were computed in order to give a general understanding of participants' biographic profile. This enabled an understanding of the variables, existing relationships and characteristics of the sample hence accuracy of facts (Sekaran, 2016, p. 279-280). To test the model, spearman rank correlations were first computed between the variables to measure their strength. ANOVA was used to test the normality of the distribution with means equal to the slope coefficients of predictor variables. Nonparametric Kruskal-Wallis test was used in cases where there were too small samples. Afterward, multiple regression analysis was conducted on the suggested variables enabling identification of the influence of the predictor variable on unemployment.

\section{RESULTS}

This paper uses the responses of 120 young people to the survey. A description of the participants' profile is presented in Table 1 . The majority of black race $67.5 \%$ responded to the questionnaire. There were $75.8 \%$ of skilled participants and $43.3 \%$ held a degree while $35.8 \%$ held either a certificate or diploma. Nearly all (88.4\%) respondents were in the age group between 15 years and 30 years.

Table 1 Participants' Profile

\begin{tabular}{|l|l|}
\hline Demographic profile & Percentage \\
\hline Age & \\
\hline $15-24$ & 54.2 \\
\hline $25-30$ & 34.2 \\
\hline $30-35$ & 11.7 \\
\hline Race & \\
\hline Black & 67.5 \\
\hline White & 15.0 \\
\hline
\end{tabular}


Journal of Social Sciences (COES\&RJ-JSS), 7(2), pp.86-102

\begin{tabular}{|l|l|}
\hline Demographic profile & Percentage \\
\hline Indian & 4.2 \\
\hline Coloured & 13.3 \\
\hline Skills possessed & \\
\hline Skilled & 75.8 \\
\hline Semi-skilled & 24.2 \\
\hline Education level & \\
\hline Grade 12 & 20.8 \\
\hline Certificate/Diploma & 35.8 \\
\hline Degree & 43.3 \\
\hline
\end{tabular}

The respondents were asked to indicate whether they have remained unemployed for at least three years. From Table 2, it is clear that the majority of the respondents 60.8 have remained without work in the past three years while $39.2 \%$ had some work they were doing, meaning that they were either employed or were self-employed. The respondents were then asked to give reasons for not getting employed (see Table 3 below). The most frequently-quoted reasons were: "I do not have the minimum experience" (mentioned by $40 \%$ of respondents); "I don't have the required skills" (mentioned by $17.5 \%$ ) while a few 3.3\% mentioned that "looking for employment is expensive". It is also interesting to note that a considerable percentage (39.2\%) of study participants did not respond to this questionnaire item. Lastly, it was also evident from the study that the majority of respondents $58.3 \%$ had never come across opportunities such as internships, scholarships or in-service training that would expose them to the 'world of work'.

Table 2 Frequency percentage with which participants were unemployed for the last 3 years

\begin{tabular}{lll}
\hline & Frequency & Percent \\
\hline Yes & 73 & 60.8 \\
No & 47 & 39.2 \\
\hline Total & $\mathbf{1 2 0}$ & $\mathbf{1 0 0 . 0}$ \\
\hline
\end{tabular}

Table 3 Reasons for not getting employed in the last three years

\begin{tabular}{lll}
\hline & Frequency & Percent \\
\hline I do not have the required education & 21 & 17.5 \\
I do not have the minimum experience & 48 & 40.0 \\
Looking for employment is expensive & 4 & 3.3 \\
No response & 47 & 39.2 \\
\hline Total & $\mathbf{1 2 0}$ & $\mathbf{1 0 0 . 0}$ \\
\hline
\end{tabular}

Table 4 Results of crosstabulation of educational qualification and economic status

\begin{tabular}{lllll}
\hline Educational Qualification & \multicolumn{3}{l}{ Economic status } & Total \\
\cline { 2 - 4 } & & Skilled & Semi-Skilled & \\
\hline \multirow{2}{*}{ Grade $\mathbf{1 2}$} & Count & 0 & 25 & 25 \\
& Expected Count & 19.0 & 6.0 & 25.0 \\
\hline
\end{tabular}




\begin{tabular}{|c|c|c|c|c|}
\hline & $\begin{array}{l}\% \text { within } \\
\text { qualification }\end{array}$ & educational0.0\% & $100.0 \%$ & $100.0 \%$ \\
\hline \multirow{3}{*}{ Certificate/Diploma } & Count & 39 & 4 & 43 \\
\hline & Expected Count & 32.6 & 10.4 & 43.0 \\
\hline & $\begin{array}{lr}\% & \text { within } \\
\text { qualification }\end{array}$ & educational90.7\% & $9.3 \%$ & $100.0 \%$ \\
\hline \multirow{3}{*}{ Degree } & Count & 52 & 0 & 52 \\
\hline & Expected Count & 39.4 & 12.6 & 52.0 \\
\hline & $\begin{array}{l}\% \quad \text { within } \\
\text { qualification }\end{array}$ & educational100.0\% & $0.0 \%$ & $100.0 \%$ \\
\hline \multirow{3}{*}{ Total } & Count & 91 & 29 & 120 \\
\hline & Expected Count & 91.0 & 29.0 & 120.0 \\
\hline & $\begin{array}{l}\% \quad \text { within } \\
\text { qualification }\end{array}$ & educational $75.8 \%$ & $24.2 \%$ & $100.0 \%$ \\
\hline
\end{tabular}

With a $x^{2}=100.204, \mathrm{df}=2$ and Asymp. Sig. 2-sided $=0.000$, the study established a dependence between education levels and the status of the young people studied in the labour market. Similarly, the study did not establish any interdependence between the level of education qualification of the population under study and the unemployment status $\left(x^{2}=3.912, \mathrm{df}=2\right.$ and Asymp. Sig. 2 -sided $=0.141$ ). ANOVA test results of difference among races and unemployment showed that there was a significant difference between the groups (Levene statistic $=23.864 ; p=.008 ; \mathrm{df}=3$ ).

Table 5 Results of crosstabulation of educational qualification and unemployment

\begin{tabular}{|c|c|c|c|c|}
\hline \multirow{2}{*}{\multicolumn{2}{|c|}{ Education qualification }} & \multicolumn{3}{|c|}{$\begin{array}{l}\text { Unemployed } \\
\text { three years }\end{array}$} \\
\hline & & Yes & No & Total \\
\hline \multirow{3}{*}{ Grade 12} & Count & 11 & 14 & 25 \\
\hline & Expected Count & 15.2 & 9.8 & 25.0 \\
\hline & $\begin{array}{l}\% \quad \text { within } \\
\text { qualification }\end{array}$ & educational $44.0 \%$ & $56.0 \%$ & $100.0 \%$ \\
\hline \multirow{3}{*}{ Certificate/Diploma } & Count & 29 & 14 & 43 \\
\hline & Expected Count & 26.2 & 16.8 & 43.0 \\
\hline & $\begin{array}{l}\% \quad \text { within } \\
\text { qualification }\end{array}$ & educational67.4\% & $32.6 \%$ & $100.0 \%$ \\
\hline \multirow{3}{*}{ Degree } & Count & 33 & 19 & 52 \\
\hline & Expected Count & 31.6 & 20.4 & 52.0 \\
\hline & $\begin{array}{l}\% \quad \text { within } \\
\text { qualification }\end{array}$ & educational63.5\% & $36.5 \%$ & $100.0 \%$ \\
\hline \multirow{3}{*}{ Total } & Count & 73 & 47 & 120 \\
\hline & Expected Count & 73.0 & 47.0 & 120.0 \\
\hline & $\begin{array}{l}\% \quad \text { within } \\
\text { qualification }\end{array}$ & educational $60.8 \%$ & $39.2 \%$ & $100.0 \%$ \\
\hline
\end{tabular}


Computing the spearman rank correlation coefficients for the data above (see Table 6), it was determined that economic (skill) status relates negatively to education qualification $\left(r=-0.751^{* *}\right.$; Sig. $\left.=0.000\right)$; positively to unemployment $\left(r=265^{* *}\right.$; Sig. $\left.=0.003\right)$ and negatively to educational level $(r=-.110)$. Therefore, there is a weak linear relationship between level of education of the population studied and economic (skill) status. All relations were significant. Thus, the relationship between level of education and unemployment status is confirmed. The results mean that a recurring production of education and training into the labour market is not accompanied by a reduction in unemployment. These results agree with those of Applegate et al. (2014).

Table 6 Matrix of spearman rank correlation coefficients

\begin{tabular}{|c|c|c|c|c|}
\hline Variables & & $\begin{array}{l}\text { Economic } \\
\text { status }\end{array}$ & $\begin{array}{l}\text { Educational } \\
\text { qualification }\end{array}$ & Unemployment \\
\hline \multirow{3}{*}{ Economic status } & Correlation & 1 & & \\
\hline & Coefficient & & & \\
\hline & Sig. (2-tailed) & . & & \\
\hline \multirow{3}{*}{$\begin{array}{l}\text { Educational } \\
\text { qualification }\end{array}$} & Correlation & $-.751^{* *}$ & 1 & \\
\hline & Coefficient & & & \\
\hline & Sig. (2-tailed) & .000 & . & \\
\hline \multirow{3}{*}{ Unemployment } & Correlation & $.265^{* *}$ & -.110 & 1 \\
\hline & Coefficient & & & \\
\hline & Sig. (2-tailed) & .003 & .230 & . \\
\hline
\end{tabular}

$n=120 ; * * p<0.01$ (2-tailed).

An ANOVA was also conducted to ascertain whether differences existed between a respondents perception about unemployment with regard to education levels they possess. However, since in some instances there are too small samples, then the nonparametric Kruskal-Wallis test (one-way analysis of variance by ranks) was done. Table 7 shows the results of the tests and is evident that there is generally no statistically significant difference between education level and how respondents felt about unemployment.

Table 7 ANOVA Results of the difference with regard to unemployment perceptions and between education levels

\begin{tabular}{|c|c|c|c|c|c|c|}
\hline Perception & Education level & $\mathrm{n}$ & Mean & $\begin{array}{l}\text { Std. } \\
\text { Deviation }\end{array}$ & $\begin{array}{l}\text { ANOVA } \\
\text { Sig. }\end{array}$ & $\begin{array}{l}\text { Kruskal- } \\
\text { Wallis }\end{array}$ \\
\hline \multirow{3}{*}{$\begin{array}{l}\text { Unemployment } \\
\text { one loose skills }\end{array}$} & Grade 12 & 25 & 1.44 & .507 & \multirow[t]{3}{*}{.817} & \multirow[t]{3}{*}{.790} \\
\hline & \multicolumn{2}{|c|}{ Certificate/Diploma43 } & 1.53 & .909 & & \\
\hline & Degree & 52 & 1.46 & .503 & & \\
\hline \multirow{3}{*}{\multicolumn{2}{|c|}{$\begin{array}{l}\text { Unemployment } \quad \text { Grade } 12 \\
\text { discourages individualCertificate/Diploma } \\
\text { from searching for work Degree }\end{array}$}} & 25 & 1.40 & .500 & \multirow[t]{3}{*}{.628} & \multirow[t]{3}{*}{.625} \\
\hline & & a43 & 1.42 & .499 & & \\
\hline & & 52 & 1.50 & .505 & & \\
\hline \multirow{2}{*}{$\begin{array}{l}\text { Unemployment } \\
\text { discourages }\end{array}$} & Grade 12 & 25 & 1.88 & .600 & \multirow[t]{2}{*}{.041} & \multirow[t]{2}{*}{.075} \\
\hline & nCertificate/Diplom & a43 & 1.65 & .482 & & \\
\hline
\end{tabular}




\begin{tabular}{|c|c|c|c|c|c|c|}
\hline Perception & Education level & $\mathrm{n}$ & Mean & $\begin{array}{l}\text { Std. } \\
\text { Deviation }\end{array}$ & $\begin{array}{l}\text { ANOVA } \\
\text { Sig. }\end{array}$ & $\begin{array}{l}\text { Kruskal- } \\
\text { Wallis }\end{array}$ \\
\hline $\begin{array}{l}\text { individual } \\
\text { attending school }\end{array}$ & from Degree & 52 & 1.56 & .502 & & \\
\hline \multirow{3}{*}{\multicolumn{3}{|c|}{$\begin{array}{l}\text { Unemployment makesGrade } 12 \\
\text { one feel discriminatedCertificate/Diploma43 }\end{array}$}} & 1.80 & .408 & .367 & .083 \\
\hline & & & 1.58 & .626 & & \\
\hline & & & 1.60 & .774 & & \\
\hline
\end{tabular}

The mean difference is significant at 5\%level.

\section{The Model}

To test the hypothesis more adequately, a series of statistical predictions were calculated using regression analyses. Regression analyses seek to establish a linear relationship between the attributes concerned and/or being measured. The hypotheses were tested using linear enter method (Hair, Black, Babin \& Anderson, 2010). The observed data was calculated by minimising the sum of the squares of the vertical deviations from each data point to the line. Since the deviations are first squared, then summed, then it means that there are no cancelations between positive and negative values. The least squares estimates (standardised partial regression coefficients) are $B_{2}, B_{3}, \ldots B_{n}$ and $X_{1}, X_{2}, \ldots, X_{4}=$ scores on different predictors while $Y_{t}$ is the estimated unemployment (Gujarati, Porter \& Gunasekar, 2013; Tabachnick \& Fidell, 2001:112). The regression analysis provided a predictive equation: $\boldsymbol{Y}_{t}=\boldsymbol{B}+\boldsymbol{B}_{1} \boldsymbol{X}_{1}+\boldsymbol{B}_{2} \boldsymbol{X}_{2}+\boldsymbol{B}_{3} \boldsymbol{X}_{3}+\boldsymbol{B}_{4} \boldsymbol{X}_{4}+\boldsymbol{u}$

With education level and other variables as independent and unemployment dependent, we established the multiple regression models to test $H 1$. The criteria employed to determine whether or not the hypothesis is supported include the unstandardised regression coefficient (6), probability value, $F$ statistic, amount of variance $\left(R^{2}\right)$ and adjusted $R^{2}$. The $F$-test has the null hypothesis that there is no linear relationship between the variables $\left(R^{2}=0\right)$. In this study the F-test $=8.734$ thus, highly significant at above critical values at $5 \%$ level of significance (2.29). As such, we can assume that there is a significant linear relationship between the variables in our model below.

$$
\begin{array}{lllllll}
Y=1,457-0,275 X_{1}+0,761 X_{2}+0,761 X_{3}+0,302 X_{4}+0,071 X_{5} & & \mathrm{R}^{2}=0.395 \\
s e=(0.786) & (0.076) & (0.321) & (0.152) & (0.080) & (0.144): & \mathrm{df}=5 \\
t=(1.853) & (-3.598) & (2.373) & (1.982) & (0.887) & (-1.042): & \text { Adj. } \mathrm{R}^{2}=0.349
\end{array}
$$

The results depict a positive relationship between unemployment and education level (see Table 8). The slope coefficient of 0.302 means that the percentage change in unemployment is approximately $30 \%$, implying that if an increase in level of education occurs by $1 \%$, on the average unemployment goes up by approximately $30 \%$. However, this happens only if the other variables are held constant. The intercept value (approx. 1) means that the average increase in unemployment would be nearly 1 if the independent variables were held constant. Nonetheless, the intercept term may not have an economic significance (Gujarati and Porter, 2013). While race and training show a negative relationship with unemployment, $\mathrm{R}^{2}$ value of 0.395 means that approximately $40 \%$ of the variation in unemployment rate is explained by the model, that is, five explanatory variables. This means that the model chosen fits the actual data. 


\section{Statistical significance of the model}

Considering the slope coefficient, the computed $t$-values under the assumption true population value of each regression coefficient individually is zero are (1.853), (-3.598), (2.373), (1.982), (0.887), (-1.042). The reported $t$-values demonstrate that each estimated regression coefficient is not individually statistically significant ( $\mathrm{df}=72 ; p<$ 0.05 ; sig. $=1.980$ [two-tailed]). Furthermore, for each computed absolute $t$-value shown in the equation, there are some falling below critical $t$-values therefore, means that each regression coefficient individually is zero.

Table 8 Relationship coefficients

\begin{tabular}{llllll}
\hline Variable & $\boldsymbol{B}$ & t-value & $\begin{array}{l}\text { Sig. } \\
\text { Level }\end{array}$ & Tolerance & VIF \\
\hline (Constant) & 1.457 & 1.853 & .068 & & \\
Race category & -.275 & -3.598 & .001 & .595 & 1.682 \\
Economic status & .761 & 2.373 & .021 & .341 & 2.934 \\
Educational qualification & .302 & 1.982 & .052 & .379 & 2.640 \\
Demarcation Zone & .071 & .887 & .378 & .643 & 1.556 \\
Skill acquisition opportunities & -.150 & -1.042 & .301 & .868 & 1.152 \\
\hline
\end{tabular}

a. Dependent Variable: Unemployment category

Regression is significant at $* p<0.05$

\section{DISCUSSION AND CONCLUSION}

This study empirically investigated the relationship between education level and unemployment in a historically disadvantaged rural context. Whereas there is a positive relationship between education level and unemployment, however, we find no robust evidence about the linkage between the constructs. Besides, significant differences were exhibited among races as concerns unemployment. In the short-term, unemployment is unlikely to come down in South Africa without fundamental improvements and political will. As such, continuous group efforts among relevant stakeholders are necessary to try finding solutions to unemployment. Such solutions should connect with national development priorities and international agenda with education outcomes demonstrating relevance to such priorities. Higher learning/training institutions should continuously revise their programmes to reflect changes in the job market, as well as develop new courses in accordance to labour signals. Meaningful linkages with industry could enable trainees have internships thus open opportunities for high achievers to be absorbed by the same industry. Government should unceasingly enact economic reforms e.g. streamlining the labour market system that would promote private sector and entrepreneurship since educational achievements have association with entrepreneurship. This could help in reducing unemployment and develop South Africa as a high income country. Geographical imbalances may be addressed by encouraging mobility to help reduce structural unemployment at national level as those seeking employment may benefit from the dynamics offered by highly competitive regions. To reduce long-term unemployment, education should remain a top agenda for decisionmaking for the reason that a more educated populace is a more employed populace. 
Similar to other investigations, this study had limitations. It was only conducted in one locality and the sample size was not large, hence, generalisation of the findings is limited. Therefore, similar studies, in other provinces, can be conducted to provide more fruitful insights and extend the generalisability of the findings. Moreover, future research could dwell into finding other issues responsible for increasing unemployment in the country.

\section{References}

Acemoglu, D. (1997). Training and Innovation in an imperfect labour market. The Review of Economic Studies, 64 (3), 445-464.

Applegate, J., Chiem, P., \& Sanders, C. (2014). Education and unemployment rates before and after the great recession. Retrieved from https://smartech.gatech.edu/.../EducationandUnemploymentLevelsBeforeandAfterthe...

Archer, E., \& Chetty, Y. (2013). Graduate employability: Conceptualisation and findings from the University of South Africa. Progressio, 35(1), 134-165.

Baah-Boateng, W. (2015). Unemployment in Ghana: A cross sectional analysis from demand and supply perspectives. African Journal of Economic and Management Studies, 6(4), 402 - 415. doi: http://dx.doi.org/10.1108/AJEMS-11-2014-0089.

Becker, G. S. (1975). Human Capital (2nd ed.). Chicago: University of Chicago Press.

Bernal-Verdugo, L. E., Furceri, D. \& Guillaume, D. (2012). Labour market flexibility and unemployment: New empirical evidence of static and dynamic effects. IMF Working Paper 12/64. Washington, D.C.: United States. Retrieved from adapt.it/.../bernal_verdugo_furceri_guillaume_labour_market_flexibility_2013_64.p.

Blanchard, O., \& Johnson D. R. (2013). Macroeconomics. Harlow: Pearson.

Bless, C., Higson-Smith, C., \& Sithole, S. L. (2013). Fundamentals of social research methods: An African perspective (5th ed.). Lusaka: Juta \& Company Ltd., Paarl Media Paarl.

Cazes, S., \& Verick, S. (2013). Perspective on labour economics for development. New Delhi: ILO.

Cloete, A. (2015). Youth unemployment in South Africa: $A$ theological reflection through the lens of human dignity. Missionalia-Southern African Journal of Mission Studies, 43(3): 513 - 525. doi: http://dx.doi.org/10.7832/43-3-133.

Construction Industry Development Board. (2015). Labour and Work Conditions in the South African Construction Industry: Status and Recommendations. Retrieved from www.cidb.org.za/.../Labour\%20and\%20Work\%20Conditions\%20in\%20the\%20South.

Cooper, R. D., \& Schindler, S. P. (2008). Business research methods (8th ed.). New Delhi: Tata McGraw-Hill Publishing Company Limited. 
Corneli-Ben, T., \& Hubler, O. (2005). Downward Wage Rigidity and labour Mobility. Discussion Paper Series IZA DP No. 1523. Institute for the Study of Labour, Hannover: Germany. Available at: http://ftp.iza.org/dp1523.pdf.

Creswell, J. W. (2014). Research design: Qualitative, quantitative and mixed methods approaches. Thousand Oaks, CA: Sage Publications, Inc.

Creswell, J.W. (2015), "Research Methods", 4th ed, Lincoln: Sage Publications.

Cutler, D. M., Huang W., \& Lleras-Muney, A. (2015). When does education matter? The protective effect of education for cohorts graduating in bad times. Social Science \& Medicine 127, 63-73.

Dae-Bong, K. (2009). Human Capital and its Measurement. Paper presented at the $3^{\text {rd }}$ OECD World Forum on "Statistics, Knowledge and Policy" Charting Progress, Building Visions, Improving Life, 27-30 October 2009, Busan, Korea. Accessed at: www.oecd.org/site/progresskorea/44109779.pdf

Department of Basic Education (DBE). (2011). South African country report: Progress on the implementation of the regional education and training plan. Pretoria, South Africa: DBE.

Dimian, G. C. (2015). Labour market mismatches and age group unemployment in romania and other six CEE countries. Petroleum - Gas University of Ploiesti Bulletin, Technical Series 67,103-113.

Eiselen, R. J., Uys, T., \& Potgieter, N. (2005). Analysing survey data using SPSS 13: A workbook. Johannesburg: University of Johannesburg Press.

Elgrably, N. (2006, December). The minimum wage and labour market flexibility. Economic Note - Labour Law Series. Canada: Montreal Economic Institute. Accessed at: http://www.iedm.org/files/dec06_en.pdf.

Erdem, E., \& Tugcu, C. T. (2012). Higher education and unemployment: A cointegration and causality analysis of the case of Turkey. European Journal of Education 47, 299-309.

Fernandez-Villaverde, J. (2016). Job Search Models. Philadephia, US: University of Pennyslvania.

Festus, Y., Kasonga, L., Moses, M., \& Yu, D. (2015). The South African labour market 19952013. Economic Research Southern Africa (ERSA), Working Paper 493. South Africa. Accessed at: https://www.econrsa.org/system/files/publications/working.../working_paper_493.pdf

Gaspar, K. (2009). The relationship between unemployment and health. (MA thesis, Central European University, Budapest, Hungary. Retrieved from econ.core.hu/file/download/szirak11/gaspar.pdf 
Goldin, C. (2014). Human capital. In C. Diebolt and M. Haupert (Eds.). Handbook of cliometrics. Springer-Verlag.

Griffiths, M., \& Rotheim, R. (2007). Classical and Keynesian economic explanations for unemployment. EC103: Introduction to Macroeconomics. Skidmore College: NY. Accessed at: www.inscitia.com/wpcontent/uploads/.../Michael_Griffiths_EC103H_Final_Essay.pdf.

Gujarati, D. N., Porter, C. D., \& Gunasekar, S. (2013). Basic econometrics (5th ed.). New Delhi: Tata McGraw-Hill Education Pvt. Ltd.

Hair, J. F., Black, W. C., Babin, B. J., \& Anderson, R. E. (2010). Multivariate data analysis: A global perspective. New York: Pearson Prentice Hall.

Industrial Development Corporation. (2013). South African economy: An overview of key trends since 1994. Department of Research and Information, South Africa.

Jacob, E. (2014). Twelve ways to fix the youth unemployment crisis. Governance studies at Brookings. Accessed at: https://www.brookings.edu/.../twelve-ways-to-fix-the-youthunemployment-crisis/.

Laureys, L. (2014). The cost of human capital depreciation during unemployment. Working Paper No. 505. Bank of England. Retrieved from: www.bankofengland.co.uk/research/Documents/workingpapers/2014/wp505.pdf

Lie, K. Y., Pang, V., \& Mansur, F. (2007). Employer perceptions on graduate literacies in higher education in relation to the workplace. English for Specific Purposes World. Retrieved from: http://w w w w w w w w w Articles_20/DOC/Koo_vp_employer_Journal180ct09.pdf.

Micer, J. (1991). Education and unemployment. Cambridge: NBER.

National Treasury. (2011). Confronting Youth Unemployment: policy options for South Africa. Pretoria, South Africa. Accessed http://www.treasury.gov.za/documents/national\%20budget/2011/Confronting\%20yout h\%20unemployment\%20-\%20Policy\%20options.pdf.

Nel, H., \& Neale-Shutte, M. (2013). Examining the evidence: Graduate employability at Nelson Mandela Metropolitan University. South African Journal of Higher Education, 27(2), 437-453.

Núñez, I., \& Livanos, I. (2010). Higher education and unemployment in Europe: an analysis of the academic subject and national effects. Higher Education 59, 475-487. 
Oluwajodu, F., Blaauw, D., Greyling, L., \& Kleynhans, E.P. J. (2015). Graduate unemployment in South Africa: Perspectives from the banking sector. SA Journal of Human Resource Management/SA Tydskrif vir Menslikehulpbronbestuur, 13(1). doi: http://dx.doi. org /10.4102/ sajhrm.v13i1.656.

Oreopoulos, P., von Wachter, T., \& Heisz, A. (2012). The short- and long-term career effects of graduating in a recession. American Economic Journal: Applied Economics, 4(1), $1-29$.

Riddell, W. C., \& Song, X. (2011). The impact of education on unemployment incidence and re-deployment success: Evidence from the US labour market. IZA Discussion Paper No. 5572. Retrieved from ftp.iza.org/dp5572.pdf

Rogan, M., \& Reynolds, J. (2014). Annual Eastern Cape labour review. Neil Aggett Labour Studies Unit Research Report 2. Rhodes University. Available at: www.ru.ac.za/nalsu.

Sekaran, U., \& Bougie, R., (2010). Research methods for business: A skill-building approach (5th ed.). New York: John Wiley \& Sons, Inc.

Sekaran, U., \& Bougie, R. J. (2016). Research methods for business: A skill-building approach (7th ed.). West Sussex: John Wiley \& Sons Ltd.

Sha, N. (2006). Are graduates to be blamed? Unemployment of computer science graduates in Malaysia. Retrieved from http://aabss.org/Perspectives2008/AABSS2008Article6NORSHIMAZSHAH.pdf.

Simiyu, J., \& Sambu, L. (2012). Nature and type of government and NGO interventions in curbing unemployment and underemployment of urban youth in Kenya. Journal of Emerging Trends in Educational Research and Policy Studies, 3(5), 730-736.

Stats SA. (2014). Mid-year population estimates. Statistical Release P0302, Statistics South Africa. Accessed at: https://www.statssa.gov.za/publications/P0302/P03022014.pdf

Stats SA. (2015). National and provincial labour market: Youth. Quarter 1 2008-Quarter 1 2015. Statistical Release P0211.4.2, Statistics South Africa. Accessed at: www.statssa.gov.za/publications/P02114.2/P02114.22015.pdf

Tabachnick, B. G., \& Fidell, L. S. (2001). Using multivariate statistics (4th ed.). New York: Harper Collins College.

Teixeira, P. N. (2014). Gary Becker's early work on human capital - collaborations and distinctiveness. IZA Journal of Labor Economics, 3(1), 1-20. Retrieved from https://izajole.springeropen.com/articles/10.1186/s40172-014-0012-2.

doi:10.1186/s40172-014-0012-2. 
The European Centre for the Development of Vocational Training, Cedefop. (2015, January). Skill set and match - Cedefop's magazine promoting learning for work. Luxembourg: Cedefop. $\quad$ Retrieved from http://www.europass.ie/europass/documents/SkillsetandMatchJan2015.pdf.

Uddin, P. S. O., \& Uddin, O. O. (2013). Causes, Effects and Solutions to Youth Unemployment Problems in Nigeria. Journal of Emerging Trends in Economics and Management Sciences, 4(4), 397-402.

Van de Rheede, T. J. (2012). Graduate unemployment in South Africa: Extent, nature and causes. MCom Thesis, University of the Western Cape, Cape Town, South Africa. Retrieved from http://etd.uwc.ac.za/xmlui/handle/11394/4497.

Van der Merwe A. (2009). A comparison of the labour market expectations and labour market experiences of new graduates. South African Journal of Higher Education, 23(2), 398-417.

Weir-Smith, G. (2014). An overview of the geographic data of unemployment in South Africa. South African Geographical Journal, 96(2), 134 - 152. 